\title{
コンピュータ水泳学習支援プログラムが子どもの 学習動機と学習方略に与える影響
}

仙石 泰雄 ${ }^{1)}$ 野村 武男 ${ }^{2)}$

\section{Effect of a computer-assisted swimming instruction program on children's learning motivation and learning strategy}

\author{
Yasuo Sengoku ${ }^{1}$ and Takeo Nomura ${ }^{2}$
}

\begin{abstract}
A study was conducted to identify the effect of a computer-assisted swimming instruction (CASI) program on children's learning motivation and learning strategy. Twenty children learning to swim in a private swimming club participated. The subjects were classified into an experimental group that used the CASI program before each swimming lesson and a control group that merely participated in the ordinary swimming lesson at the pool. Learning motivation, learning strategy, and 50-m swimming performance for the front crawl and breaststroke were investigated before and after the swimming lesson. The experimental group showed significantly higher fulfilment-oriented motivation $(\mathrm{p}<0.05)$ and a tendency to have higher practice- and performance-oriented learning motivation. Using the CASI program developed to enhance swimming performance, it was indicated that the children's motivation to obtain a higher performance level increased, even though it did not necessarily result in higher performance improvement. The CASI program also enhanced enjoyment of the instruction program and interest in swimming as a sport itself, and therefore it may be utilized beneficially in an educational setting.
\end{abstract}

\section{Key words : learning materials, swimming performance}

(Japan J. Phys. Educ. Hlth. Sport Sci. 52: 161-171, March, 2007)

1）筑波大学体育センター

干 305-8574 茨城県つくば市天王台 1-1-1

2) 筑波大学人間総合科学研究科

干 305-8574＼cjkstart茨城県つくば市天王台 1-1-1

連絡先 仙石泰雄
1. University of Tsukuba, Physical Education Center 1-1-1 Tennodai, Tsukuba, Ibaraki 305-8574

2. University of Tsukuba, Comprehensive Human Science

1-1-1 Tennodai, Tsukuba, Ibaraki 305-8574

Correspondingauthorssengoku@sapec.tsukuba.ac.jp 
キーワード: 学習教材, 泳パフォーマンス

\section{I 緒言}

近年のコンピュータサイエンスの発展に伴い， 新しい学習教材としてコンピュータを活用した学 習支援 (Computer Assisted Instruction：以下 CAI と略す）プログラムの開発が進められてい る. CAIプログラムに関する研究も多くされて おり，様々な活用事例や活用効果が報告されてい る.

Steffen and Hansen（1987）は, 大学生を対象 としたボウリングの授業にCAI プログラムを活 用することで，ボウリングの技能学習を有意に改 善し, 学習への楽しみを増大することに有効な作 用があることを報告している，また，日本国内で もマット運動を対象にしたCAIソフトの開発・ 研究が進んでおり, コンピュータで模範演技の動 画を見せることで運動動作への気付きを促し，動 きのイメージがつかみやすくなり, 技能達成や習 熟に寄与したことが報告されている(鈴木, 2001).

水泳は, 水中で行われる特殊な運動であり, 動 作に関する情報の多くが水中にあることから，水 中動作の映像を利用して学習を進めることの有用 性が指摘されている（高橋ほか，1985）。そのた め水泳に打いてマルチメディアコンテンツを含ん だCAIプログラムの利用価值は高いと考えられ る. Persyn and Colman（1999）は, 大学生を対 象に動作診断能力の育成を目指すCAI プログラ ムを開発し，その有用性を分析し，CAIコンテ ンッの表示方法についての問題点を指摘した。ま た, Sengoku and Nomura（2003）は, 小学校高 学年児童を対象にインターネットを利用した CAI プログラムを開発し，マルチメディアコン テンッは泳動作に対する理解を高め, 文字情報を 用いた大学研究者との双方向の情報通信は学習に 対する楽しみを増大させることを報告した。

CAI プログラムの有用性や活用の可能性が示 されている一方で, McKethan et al. (2000) は CAI プログラムの活用は従来の授業方法と比較 して有効な効果が望めないことを報告している.
Sengoku and Nomura（2003）の報告においても, CAI プログラム利用群と非利用群との間に興味 関心・知識・技能に関する学習効果の差を見出す ことは出来なかった.

このようにCAI プログラムの活用に関して一 定の見解がえられていない理由として, 先行研究 におけるCAI プログラムの活用目的が, 認知能 力・動作診断能力・技能の向上と多岐にわたって いることがあげられる。また, 利用対象者が小学 生から大学生と多様であり, CAI プログラムの 有用性を明らかにするためには，対象者の学習プ ロセスに合わせた利用目的と利用方法の検討がな されなければならない。

小学生を対象としたCAI活用の研究結果とし て, 賀川・石井 (2000) は学習支援ソフトが学習 への意欲喚起の効果があること示している，さら に, Sengoku and Nomura (2003) もCAI Web Siteの利用が学習への楽しみを増大させる可能性 を報告している。これらの研究結果より, 小学生 を対象としたCAI プログラムの利用効果として 学習への動機づけの可能性が考えられるが, CAI プログラム活用による個々の学習動機の変化を分 析した研究はまだ十分に行われているとは言えな い.

本研究は, 子どもの水泳学習に利用が可能なコ ンピュータ学習支援プログラムを開発し，コンピ ユータ学習支援プログラムが子どもの学習動機と 学習方略に与える影響を明らかにすることを目的 とする。

\section{II 方法}

\section{CAIプログラムの開発}

Sengoku and Nomura（2003）と野村ほか （2003）によって開発された水泳学習支援システ ムを元に，クロールと平泳ぎの泳技能向上を目指 した水泳 CAI プログラムを作成した。本CAI プ ログラムは，すでに基本的な泳技能を獲得してお り, さらにより高度な泳技能の習得を目指す子ど もを対象とした。CAI プログラムは，水泳実技 指導の時間外で利用する予習・復習教材として実 


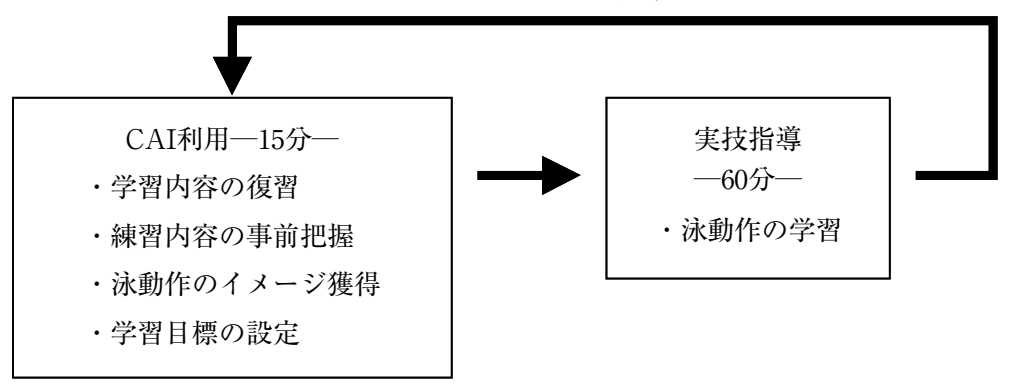

図1 CAI プログラム活用の流れ

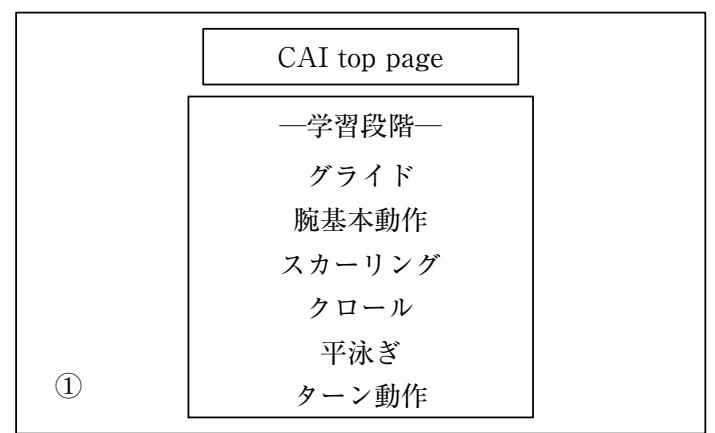

(1)6つの学習段階で構成

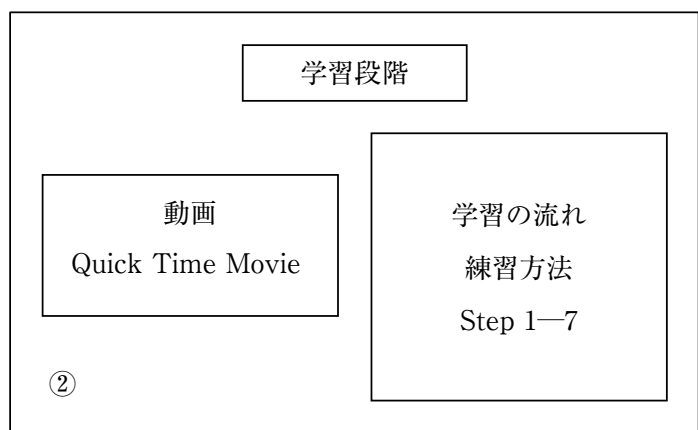

(2)各学習段階の学習の流れ及び練習方法の提示

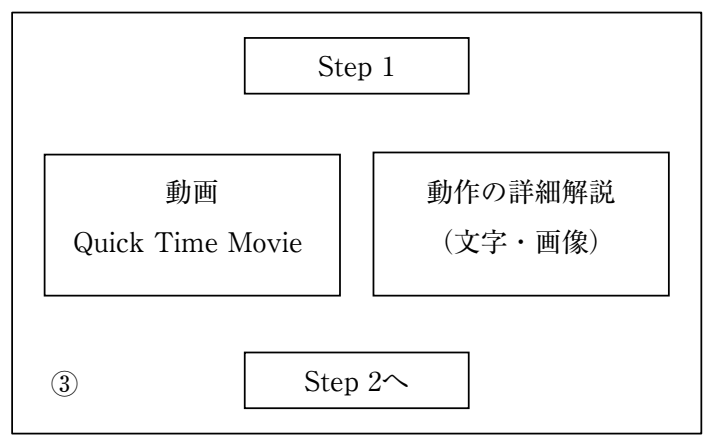

(3)練習方法に関する詳細支援情報

図2 水泳コンピュータ学習支援プログラムの概要と画面 構成
技指導の直前に 15 分間活用した（図 1).プログ ラム利用者は, 当日学習するプログラム内容に関 する支援情報を自由に閲覧し，前回までのプログ ラム内容の復習をする時間も設けられた。実技指 導前に, 当日学習する実技内容についての支援情 報を得ることにより，練習内容の把握や学習する 泳動作に対するイメージを獲得することで, 明確 な学習目標を設定し, 学習内容を深めることを可 能にすることを目的とした。

水泳 CAI プログラムの構成概要を図 2 に示し た. CAI プログラムは 6 段階の指導内容（グライ ド・腕基本動作・スカーリング・クロール・平泳 ぎ・ターン動作）で構成した（図2(1)）。過去に 開発されたCAIプログラムは，練習方法につい ての情報支援が不足しており，学習成果に結びつ かなかったことが問題点として挙げられていたた め（野村ほか，2003），本実験におけるCAI プロ グラムには各学習段階ごとに学習の流れに沿った 練習方法に関する支援情報を中心に掲載した（図 2(2)). 練習方法に関する情報は，一流競泳選手 が導入している技術練習内容であった。さらに， 各練習方法に関する詳細な解説を動画・静止画 · 文字情報にて提示し, 支援情報を収集した後に次 の練習段階へ移行できるように設定された（図 2 (3)).

実際の CAI プログラムの具体画面を眓 3 に示し た. CAI プログラムは, HTML書式で作成され， ハイパーリンクにてそれぞれの支援情報に学習プ ロセスに合わせて移動できるように構成した。支 援情報として, 目的とする動作の動画をQuick 


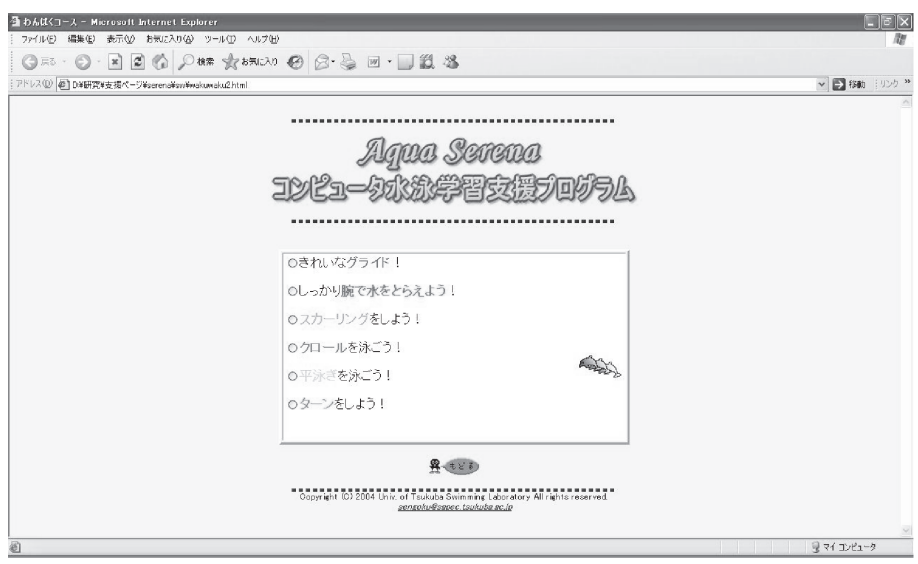

(1)Topページ : 1〜6の学習段階へ進めるように作成

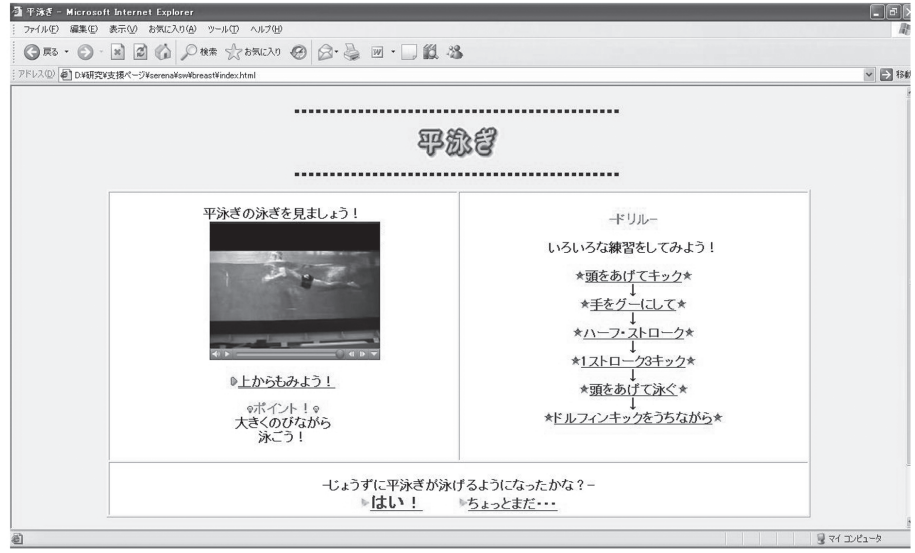

(2)学習段階5（平泳ぎ）ページ：各練習ステップへ進めるように作成

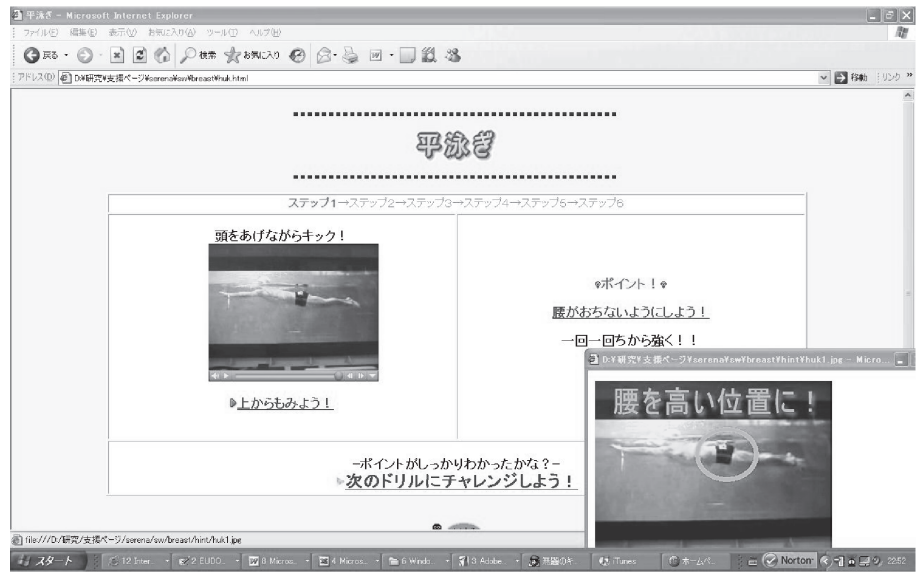

(3)ステップ 1 : 練習内容の情報を動画・静止画・テキストにて提示

図３水泳コンピュータ学習支援プログラムの具体画面 
Time Movie ${ }^{\text {i⿱ 1) }}$ にて提示した（図3(2)，(3)）。動 画は, 水中と水上からの映像を利用し, 利用者の 目的に応じてそれぞれの映像ページに移動できる ようにした，動画情報の横に，動作の中で着目す べき内容をテキストによって説明文を加えた。さ らに，説明文をクリックすることによりテキスト 情報が説明している箇所の静止画像を提示し, 解 説内容の理解をさらに深められるようにした（図 3(3)).

すべての練習内容についてのプログラムを閲覧 した後に，その学習段階について理解できたかを たずねるリンクが用意された（図 3 (2)）。理解で きなかったことを示す子どもに対しては練習内容 を初めから提示するようにし，理解できたことを 示した場合には閲覧していた学習段階を総括した 支援情報を提示するようにした.

動画コンテンツには, 大学水泳部に所属する一 流競泳選手による泳動作を用いた。一度再生され た動画は，何度も自由に閲覧することが可能であ り,さらにコマ送りで再生することも可能であっ た。

\section{2. 実験プロトコル}

本研究では，実技指導の内容を統一するために 民間のスイミングクラブの1クラスを対象とし，

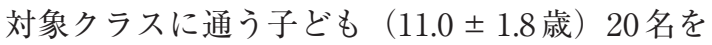
本実験の被験者として参加してもらった．被験者 は全員近代泳法 4 種目を泳げる能力を持ち，同じ クラスで週 1 回 1 時間の指導を 8 週間受けた。実 技指導の内容は，泳夕イムの短縮につながる泳技 能の向上を目的として学習プログラムが展開され た. 実験開始前に子どもの保護者と指導者に対し て実験説明会を開き, 調查内容に対してインフォ ームドコンセントを得た。被験者は, CAIプロ グラムを利用する実験群 $(\mathrm{n}=10)$ とプールでの 実技指導のみを受けるコントロール群 $(\mathrm{n}=10)$ に分けられた。プールでの実技指導は，1名の指 導者によって全員一斉指導を行った。

1 回目 (Pre) と8回目 (Post) のレッスンに被 験者の泳能力評価を行い, 2 回目から 7 回目の間 にクロールと平泳ぎの泳パフォーマンスの向上を
目指した実技指導を行った。実技指導の内容は， 事前に指導者と打合わせを行い，著者により全指 導内容が指定された。実験群は，2回目の指導か ら実技指導が始まる 30 分前にスイミングクラブ に集合し，15分間 CAI プログラムを活用した。 CAIプログラムをインストールしたコンピュー 夕を 7 台スイミングクラブのラウンジに設置し, 1 台につき $1-2$ 名の子供で活用した。 子供が CAI プログラムを活用している間 3 名の検者が補 助につき，CAI プログラム活用補助を行った。 実験群は，各学習段階ごとにCAI プログラムを 利用し，CAI プログラムに掲載された情報と当 日プールで行う実技指導の内容が統一された。

\section{3. 分析項目}

実験期間のPre とPostに子供の学習動機（実 用志向 - 優越志向 - 承認志向 - 充実志向 - 集団志 向・成績志向）と学習方略（一般・好て 努力 調整）を測定するためのアンケート調査（伊藤， 2001）を行った注2)。また，実技指導を行った日 に高橋ほか（1994）によって作成された形成的授 業評価アンケート調查を実施した注3)。両調査用 紙ともに小学校体育授業に参加する児童を対象と して作成されていたため，スイミングクラブ用に 用語の改変を行った（例：「体育では」を「スイ ミングでは」に改変).

子供の泳パフォーマンスを評価するため, Pre と Postにクロールと平泳ぎの $50 \mathrm{~m}$ 泳夕イムを 1 回ずつ測定した，測定の際は，飛び达みを行わず 水中よりスタートを行った。パフォーマンスの向 上を分析するためにPre と Post 測定值の変化率 を算出した（Pre測定值/Post測定值 × 100).

学習場面を観察するために実技指導中，2台の 固定カメラにて学習風景の撮影を行った.

\section{4. 統計処理}

全デー夕を平均土標準偏差で示した。各分析結 果の群間の差を分析するために $\mathrm{F}$ 検定の後, $\mathrm{t}$ 検 定を用いた。形成的授業評価の变化については群 内変動についてANOVAを用いて分析を行った。 また, Postでの測定における学習動機と学習方 
表 1 学習動機・学習方略結果

学習動機

\begin{tabular}{|c|c|c|c|c|c|c|c|c|c|c|c|c|}
\hline & \multicolumn{2}{|c|}{ 実用志向 } & \multicolumn{2}{|c|}{ 優越志向 } & \multicolumn{2}{|c|}{ 承認志向 } & \multicolumn{2}{|c|}{ 充実志向 } & \multicolumn{2}{|c|}{ 集団志向 } & \multicolumn{2}{|c|}{ 成績志向 } \\
\hline & Pre & Post & Pre & Post & Pre & Post & Pre & Post & Pre & Post & Pre & Post \\
\hline 実験群 & $4.10 \pm 0.77$ & $4.40 \pm 0.83$ & $3.98 \pm 0.84$ & $4.42 \pm 1.06$ & $3.00 \pm 0.91$ & $3.10 \pm 1.23$ & $4.13 \pm 0.68$ & $4.25 \pm 0.51^{*}$ & $4.25 \pm 0.69$ & $4.38 \pm 0.50$ & $3.80 \pm 1.31$ & $4.40 \pm 1.24$ \\
\hline コントロール群 & $3.51 \pm 0.98$ & $3.50 \pm 1.00$ & $3.70 \pm 1.28$ & $3.94 \pm 0.92$ & $2.73 \pm 1.07$ & $2.93 \pm 1.04$ & $3.50 \pm 0.86$ & $3.50 \pm 0.75$ & $3.93 \pm 1.03$ & $4.00 \pm 0.95$ & $3.15 \pm 1.37$ & $3.15 \pm 1.27$ \\
\hline \multicolumn{13}{|l|}{ 学習方略 } \\
\hline & \multicolumn{2}{|c|}{ 一般 } & \multicolumn{2}{|c|}{ めあて } & \multicolumn{2}{|c|}{ 努力調整 } & & & & & & \\
\hline & Pre & Post & Pre & Post & Pre & Post & & & & & & \\
\hline
\end{tabular}

実験群 $3.46 \pm 0.843 .93 \pm 0.88 * 3.07 \pm 1.043 .30 \pm 1.38 \quad 3.23 \pm 0.77 \quad 3.27 \pm 0.56$

コントロール群 $3.05 \pm 0.90 \quad 2.93 \pm 1.09 \quad 2.57 \pm 0.97 \quad 2.47 \pm 1.16 \quad 3.30 \pm 0.81 \quad 3.20 \pm 0.91$

*はPostに㧍ける群間の差を示す $(p<.05)$

略との関連を検討するために重回帰分析を行っ た.すべての分析に対して有意水準は $5 \%$ とした.

\section{III 結 果}

子どもの学習動機と学習方略の結果を表 1 に示 した. 被験者の学習動機の変化を分析した結果, Preの值にグループ間で有意な差は見られず，各 群において初期值に差はなかった。充実志向項目 は, Postにおいて実験群がコントロール群より 有意に高い值（ $p<.05 ）$ を示し，実用志向項目と 成績志向項目においても有意ではないが実験群の 測定值が高い傾向が観察された（それぞれ $p=.06)$. 学習方略を分析した結果, 一般学習方 略項目はPostにおいて実験群が有意に高い值を 示した $(p<.05)$.

重回帰分析によるPostの学習動機と学習方略 との関係の分析結果を表 2 に示した. 学習動機と 一般学習方略およびめあて方略との間に有意な重 相関係数が得られた $(p<.05)$. また, 各学習動 機尺度の影響を検討するために標準偏回帰係数を 分析したところ, 実用志向項目が一般学習方略に 対して有意な係数を示した $(p<.05)$.

形成的授業評価得点の結果を図 4 に示した。意 欲関心項目は，第 4 回目のレッスンで有意でない ものの実験群がコントロール群より高い值を示す 傾向を示し $(p=.08)$, その後高い值を維持した. 協力項目において, 第 1 回と第 4 回目のレッスン
表 2 学習動機から学習方略への重回帰分析結果

\begin{tabular}{|c|c|c|c|c|}
\hline & \multicolumn{3}{|c|}{ 学習方略 } \\
\hline & & 一般学習方略 & めあて方略 & 努力調整方略 \\
\hline \multirow{7}{*}{$\begin{array}{l}\text { 学 } \\
\text { 動 } \\
\text { 機 }\end{array}$} & 実用志向 & $0.715 *$ & 0.189 & 0.645 \\
\hline & 優越志向 & 0.245 & 0.229 & 0.727 \\
\hline & 承認志向 & -0.044 & 0.434 & -0.213 \\
\hline & 充実志向 & 0.065 & 0.217 & 0.022 \\
\hline & 集団志向 & -0.01 & -0.15 & -0.026 \\
\hline & 成績志向 & 0.094 & 0.058 & -0.512 \\
\hline & 重相関係数 & $0.935 *$ & $0.844^{*}$ & 0.672 \\
\hline & & & & $* p<$ \\
\hline
\end{tabular}

で実験群が有意に高い得点を示し $(p<.05)$, 実 験期間を通してコントロール群より高い得点を示 す傾向が示された.

被験者の泳パフォーマンスの指標として測定し た $50 \mathrm{~m}$ のタムを測定した結果を図5に示した。 クロールのタイム変化率は, 実験群において $100.31 \pm 5.54 \%$ ，コントロール群において $100.44 \pm 4.47 \%$ あ゙あた. 平泳ぎのタイム変化率 は，実験群において $101.78 \pm 6.38 \%$ ，コントロー ル群において $102.63 \pm 6.10 \%$ あった．両群とも に有意なパフォーマンスの向上は見られず， 2 群 間に有意なパフォーマンス向上の差は見られなか った。

実技指導中に測定した映像より，CAI プログ ラムの支援情報との統一性を検証した。学習段階 5 (平泳ぎ）における実技指導内容の時間配分を 

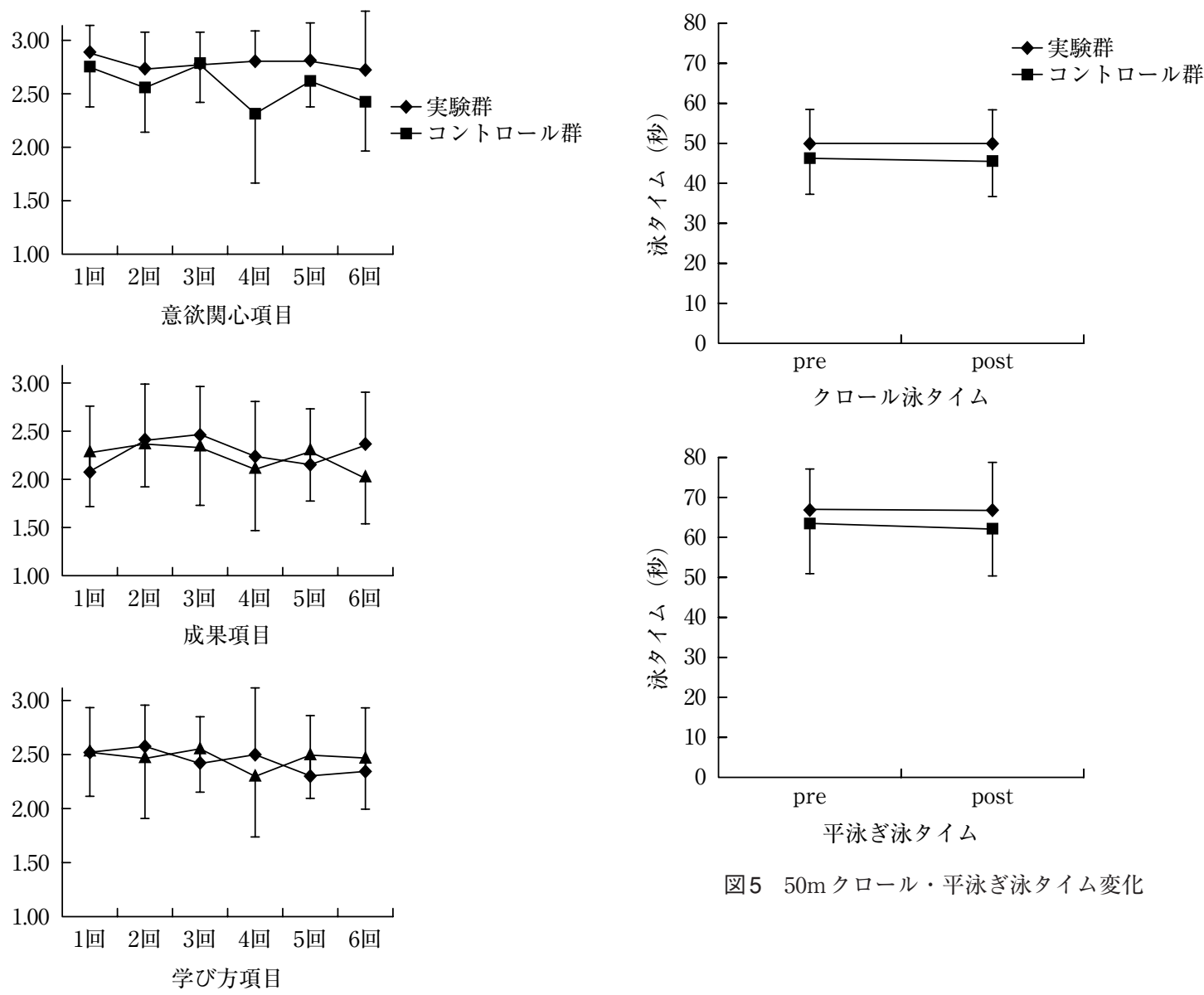

図5 $50 \mathrm{~m}$ クロール・平泳ぎ泳タイム変化

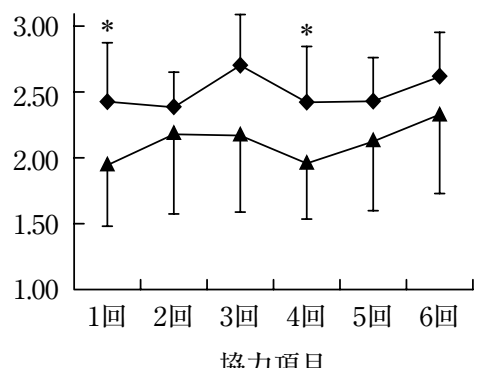

\section{IV 考察}

本研究は, 水泳学習用のCAI プログラムを開 発し, CAI プログラムの活用が子供の学習動機 と学習方略に与える影響を明らかにすることを目 的とした。スポーツの学習現場を対象とした研究 では, 指導者による指導内容により学習効果の違 いが顕著に表れることが考えられる，そのため，

図4 形成的授業評価得点推移 *は群間の差を示す $(p<.05)$

図 6 に示した（各step 内容は図 3 参照).すべて の指導日においてCAI プログラムに含まれた練 習内容が網羅されており，CAI プログラムを活 用して学習した動作を当日プールにおいても動作 の学習を行っていた。

CAI プログラムのように補助的に活用する学習 教材の効果を分析するためには，実技指導による 学習効果を統一することが有益な研究デー夕を収 集する上で最も重要となる.そのため本研究では, 指導の一貫性を重視し，スイミングクラブにおけ る一クラスを研究の対象としてCAI活用研究を 実施した。スイミングクラブにおいては，効率的 な指導を可能とするため 1 クラスの人数が 20 名 前後に通常設定されている. そのため, 本研究に 


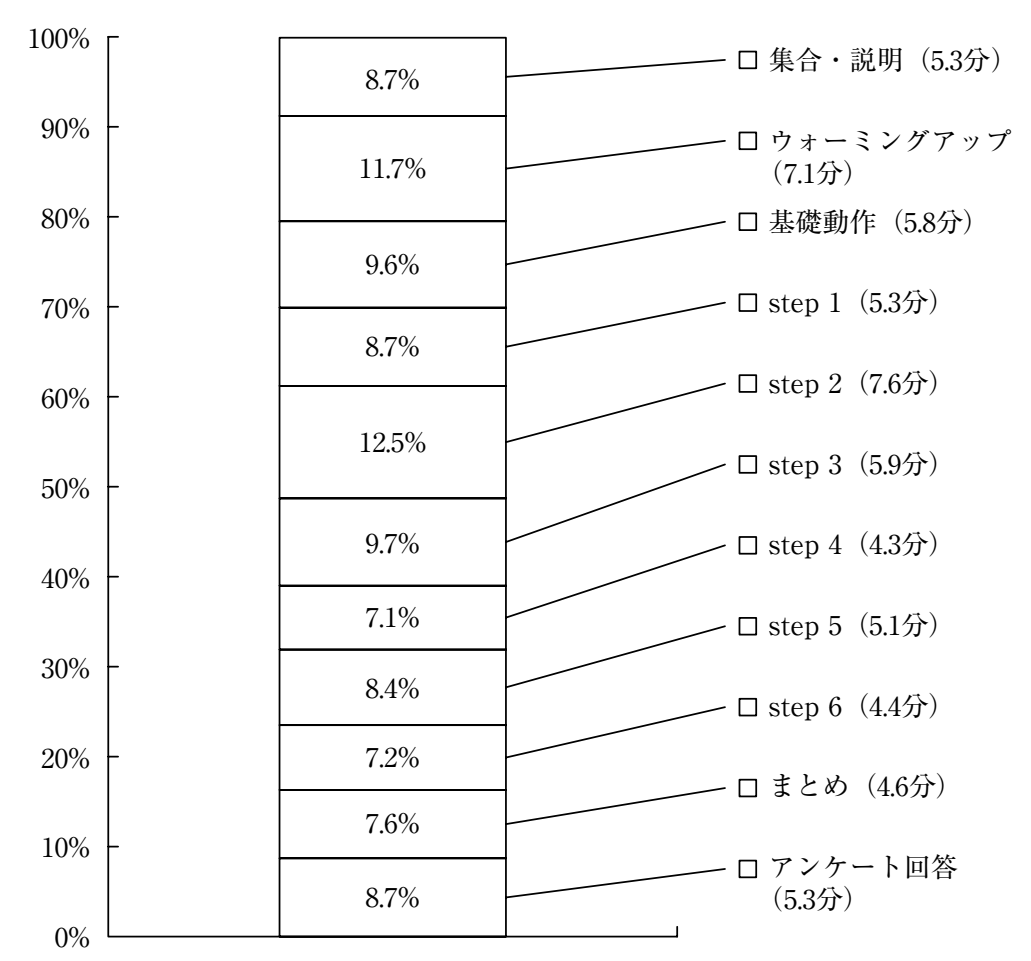

図6 学習段階5（平泳ぎ）における実技指導内容時間配分

各 step 内容は図 1 を参照

おいて対象としたクラスに参加する子どもをすべ て対象にしたものの，参加者が 20 人に限定され たが，学習内容を厳密に統制することにより CAI プログラムの活用効果を明らかにすること とした.

実験終了時に各群の学習動機を測定した結果, 実験群において充実志向項目が有意に高い值を示 した. 充実志向項目は, 教材や授業への動機を評 価しており，同一の実技指導プログラムを実施し たとしても，CAIプログラムを実技指導直前に 利用することにより, 泳技能の向上を目的した学 習プログラムに対する興味を増大できることが示 唆された. 形成的授業評価の意欲関心項目におい ても実験群でより高い得点を示す傾向が見られ， 実験期間を通して高い意欲関心を維持すことがで きたことも推察された. Steffen and Hansen （1987）は，CAI プログラムの利用は伝統的な指 導法と比較して学習者に対して学習の楽しみを増 大させることを報告している.本研究においても,
CAI プログラムを 15 分の短時間利用することに よって本実験で導入した学習プログラムに対する 意欲関心を高めることができ, 充実志向項目動機 の向上が起因している可能性が考えられた。

成績志向学習動機と実用志向学習動機は, 有意 でないものの実験群でより高い值を示す傾向が Post測定によって観察された（それぞれ $p=.06)$. 成績志向項目は体育の成績への動機である. 本研 究はスイミングクラブで行った実験であり, 泳夕 イムの短縮につながる泳パフォーマンスの向上を 目的として学習プログラムが展開された。その中 で，実験期間前後に測定した $50 \mathrm{~m}$ タイム測定結 果で泳パフォーマンスを評価したことから，成績 志向項目は泳夕イムの向上に対する動機であると 考えられる。 また，実用志向項目は，健康や体力 向上における体育の価值を認識し，運動そのもの を楽しもうとする動機である。そのため本研究に おいては，CAI プログラムを使うことにより水 泳運動を楽しみたいという動機が高まった可能性 
を示していると考えられる. 先行研究によると， 高橋ら（1985）は水泳運動において学習者に泳動 作の水中映像を見せることにより学習内容を深め られることを報告している。また，マット運動の 技能獲得を目的としたマルチメディアコンテンツ の活用により，コンテンツに含まれた動作に対す るイメージをつかみやすくすることができるとい う報告（鈴木，2001）に代表されるように，マル チメディアプログラムの活用が運動イメージの獲 得や動作内容の把握に有効に作用することが示さ れている（賀川・石井, 2000 ; 賀川, 2006 ; 北 川, 1994)。本研究においても, 過去の研究結果 同様にCAI プログラムを活用することにより学 習者に対して明確な泳動作のイメージを与え, CAI プログラムを活用することにより泳タイム の向上や水泳運動そのものを楽しみたいという学 習動機に影響を与えた可能性が考えられる. 今後 CAI コンテンツ内容と学習者の学習動機の変容 についてょり詳細な研究を進めることで, どのよ うな支援情報を用いることでより有効な CAI 活 用が可能であるか明らかにすることができると考 えられる。

尚，伊藤（2001）は，実用志向項目と充実志向 項目は内発的な動機を表しており, 実用・充実志 向項目にもとづく動機づけは，体育学習における 望ましい動機づけであることを報告している。本 研究はスイミングクラブでの実践ではあったもの の，CAI プログラムを活用することで実用・充 実志向項目の動機を高められる可能性が示され た.このことより, 水泳に対する内発的動機づけ を高めることが期待される本 CAI プログラムは, 学校教育現場においても水泳学習の有益な学習教 材として活用できることが考えられる。また，本 研究で開発したCAI プログラムを野村・仙石 （2003）が提案しているインターネット学習支援 モデルに応用することでより幅広い活用の可能性 も考えられる.

学習方略を測定した結果, 一般学習方略が Postにおいて実験群が有意に高い得点を示した。 一般学習方略は, 他の子供の動きを観察し模倣す るといった運動における一般的な方略を示してい
る、CAIプログラムを利用し，動画情報に目を 向けることで動きを観察するという学習方略が身 につき, プール内でも指導者や他の子どもの動作 を観察することにつながったことが考えられる. 先行研究では, 大学生を対象にCAI プログラム を動作の診断能力の育成に活用しているが（Persyn and Colman, 1999), 子どもを対象とした活 用の中でも動作の観察能力を育成できる可能性が あると考えられる. 今後, 子どもの認知レベルに あわせて, CAI プログラムの活用が泳動作に対 する観察能力にどのような影響を及ぼすか明らか にする必要がある。

CAI プログラムを実技指導前に利用すること により，学習者が明確なめあてをもって学習に臨 めることが期待されたものの, めあて学習方略に おいて両群との間に有意な差を見出すことができ なかった．今後より有効な CAI 活用を実現する ために，学習者個々の泳技能レベルにあわせた目 標設定に関する情報提供の必要性が考えられた。

重回帰分析の結果, 実用志向学習動機が強いほ ど，一般学習方略の使用を促すことが明らかにな った.これは, 伊藤 (2001) の報告と同様である. つまり, 水泳運動そのものに対する楽しみを増す ことにより，他者の観察や指導者の指示に対する 注意をより積極的に行うようになることを示して いるといえる。そして，このような学習への取り 組みを, 本研究で開発したCAI プログラムを活 用することによってより高められることが示唆さ れた。

賀川ほか（2000）は，小学生を対象としたマッ ト運動のCAI プログラムを活用した結果, 情緒 的体験や協力的な学習態度を育てる面でCAIプ ログラムは有用ではないと報告した。しかしなが ら, 本研究ではグループや仲間と学習を進めたい という集団志向学習動機は高い得点を維持し, 形 成的授業評価の協力項目においてはコントロール 群より有意に高い得点結果を示した。本研究では, 先行研究とは異なりCAI プログラムを授業時間 外に一斉に同じ場所で利用させた。そのことによ り, CAI プログラムの活用方法の工夫により協 力的な学習態度を育成することも可能であること 
が示唆された。

本研究では, $50 \mathrm{~m}$ の泳夕イムの向上に関して, CAI プログラムの活用効果を見出すことはでき なかった。これは, 小学校高学年児童を対象に CAI プログラムを活用したSengoku and Nomura （2003）による報告と一致する。この理由として, 本 CAI プログラムで提示した支援情報が，本実 験に参加した子どもの泳能力と比較して高度過ぎ たことが挙げられ，提示された支援情報に関する 技能を 1 回の実技指導で十分に理解することが困 難であったことが考えられる. 今後, 対象とする 子どもの泳能力にあわせた支援情報を精選する必 要があると言える。しかし, 高度な支援情報を含 めることで子どもの学習動機を高めることができ ることも考慮する必要がある.

さらに, 週 1 回 1 時間の練習では, 泳技能を向 上させるのに十分は時間をさくことが出来なかっ たことも考えられる. Steffen and Hansen (1987) は，実技の前にCAI プログラムを利用すること により，実技中に技能練習に当てる時間を増大す ることができ，より有効な技能向上の効果がある ことを報告している. 本研究では, 実技指導を両 群とも統一したため, CAI プログラムを活用し たことによる動作の説明時間の短縮という効果を 引き出すことができなかった. CAI プログラム の活用に応じて練習方法に関するインストラクシ ヨン場面を短縮するといった実技指導プログラム の改変の必要があると考えられる.しかしながら， CAI プログラムの活用により学習動機が高まっ たことは, 運動の継続につながると考えられ, 長 期的には運動技能の有意な改善につながることが 期待される.

\section{V 結 論}

本研究において, 水泳学習用の CAI プログラ ムを開発し, CAIプログラムの活用が子供の学 習動機と学習方略に与える影響を分析した。その 結果, CAI プログラムを活用することで, 指導 内容に対する興味を高められることが明らかとな った。また，CAIプログラムの活用を通して，
運動動作に対する観察能力の育成の可能性も推察 された。

水泳は水環境の影響を受けるため，実技現場で CAI プログラムを活用することは困難である. しかし，本研究では実技指導前の短時間の間 CAI プログラムを活用することで，十分に子供 の学習動機を向上させ，学習方略を改善すること が可能であることが明らかとなった。本研究で用 いたCAI プログラムの導入方法は，学校現場で も実践が可能であり，より効果的な水泳学習を展 開する一助となると考えられる。

\section{注}

注 1) Quick time movie とは, Apple Computerが 1990 年に発表したデジタルビデオのフォーマッ 卜形式である。ビデオカメラ等で撮影した動画 を高品位・高圧縮の再生が可能であり, インタ ーネット上で動画を公開するのに適した動画形 式の一つである.Quick Timeは, 米国およびそ の他の国で登録されている Apple Computer, Inc. の商標である.

注 2）伊藤（2001）によって作成された学習動機・学 習方略測定法は, 小学校高学年児童を対象とし たものである。学習動機の測定に関しては, 運 動能力・関心・意欲・態度を総合的に評価する 近年の体育授業目的に合わせ，内発的・外発的 動機づけについて詳細な分析が可能となってい る（6因子：実用志向・優越志向・承認志向・充 実志向・集団志向・成績志向).また学習方略は, 児童の学習のしかたや学習方法を 3 因子（一般学 習・めあて・努力調整）より分析が可能である. 各因子に関する定義については伊藤の解釈に従 うこととする。

注3）高橋ほか（1994）によって作成された形成的授 業評価法は，子どもが 1 時間の体育授業をどのよ うな観点から捉え，評価するかを分析すること を目的としている４４因子（意欲関心・成果・学 び方・協力）から構成された計 12 項目の調查表 からなり，簡便かつ短時間で測定が可能であり， 体育科教育領域において幅広く用いられている 調査法である。 


\section{文献}

伊藤豊彦（2001）小学生における体育の学習動機に

関する研究：学習方略との関連および類型化の試 み. 体育学研究, $46 ： 365-379$.

賀川昌明（2006）体育学習に抒けるパーソナルコンピ ユータ利用の展望と課題. 体育学研究, 51：409420.

賀川昌明・石井源信（2000）マルチメディア型マッ 卜運動学習支援ソフトの開発と小学校体育授業で の試用. 日本教育工学雑誌, 24 (Suppl.)：29-34. 北川 隆（1994）パソコンを使った体育授業の実践 例・鉄棒運動の授業 (小学校)。体育科教育, 42 (11) : 37-40.

McKethan, R., Everhart, B., and Stubblefield, E. (2000) The effect of a multimedia computer program on preservice elementary teachers' knowledge of cognitive components of movement skills. Physical educator, 57 (2): 58-68.

野村武男・仙石泰雄（2002）インターネットを利用 した水泳指導・学習支援システム。体育科教育, (6) : 58-59.

野村武男・椿本昇三・西嶋尚彦・下山好充 (2003) インターネットを利用した水泳指導・学習支援シ ステムの構築一マルチメディア技術の導入一. 筑 波大学体育科学系紀要, pp. 135-137.

Persyn, U. and Colman, V. (1999) Problems of physi- cal education students in making a kinesiological diagnosis of swimmers. In: Keskinen, K.L. (ed.) Biomechanics and Medicine in Swimming VIII. Gumnerus Printing: Finland, pp. 481-487.

Sengoku, Y. and Nomura, T. (2003) Effect of different computer assisted instruction web site contents on swimming instruction of elementary school children. In: Chatard, J.C. (ed.) Biomechanics and Medicine in Swimming IX. Publications de I'University de Saint-Etienne: France, pp. 592-597.

Steffen, J. and Hansen, G. (1987) Effect of Computerassisted instruction on development of cognitive and psychomotor learning in bowling. Journal of teaching in physical education, 6: 183-191.

鈴木美江（2001）自発性,自主性を高め一人一人を伸 ばす学習指導に関する研究—器械運動における学 習支援ソフトの開発と有効活用について一. 平成 12 年度埼玉県長期研修教員研究報告書.

高橋伍郎 - 椿本昇三 · 阿江通良 - 松下雅雄 - 坂田勇 夫 ・寄金義紀（1985）大学正課体育における光学 機器の効果的利用に関する研究一水泳授業への VTR 導入の害態一. 大学体育研究, (7) $: 1-9$. 高橋健夫 · 長谷川悦二 ・ 刏谷三郎（1994）体育授業 の「形成的評価法」作成の試み：子どもの授業評 価の構造に着目して。体育学研究, 39：29-37.

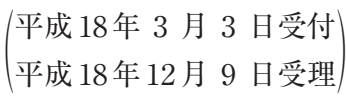

